\title{
Release the River: Mal(e)development, Dams, and the Injustices Faced by the American Indians and Nubians
}

Samar Muhamad Esmail Ali

\begin{abstract}
Numerous studies have been conducted on American Indian and Nubian literatures. However, little attention has been paid to comparing the same condition of exile that both cultures experienced as a result of building dams in their home lands. This article aims at studying the subject matter of building dams as an aggression to nature and natural elements (especially water), as well as a reason of many injustices faced by American Indians and Nubians alike.
\end{abstract}

\section{Keywords}

American Indians, Nubians, dams, water, exile, sense of place, deterritorialization, reterritorialization, Thomas King, Idris Ali.

\section{Introduction}

Since the beginning of time, water has always run gracefully and freely without boundaries. With it always comes prosperity and livelihood. Water has always been a deity who runs purposefully where life is meant to be. Most ancient civilizations worshipped water and praised it in both love and fear. For water is a merciful god who grants life and also a mighty one who claims back the life it has given -through droughts as well as floods- when man interrupts its cyclic nature and interferes with its flowing course. People respected the life of the rivers as well as that of their inhabitants for thousands of years. For example, American Indians offered their rivers food, corn meal, and tobacco in order to please the soul of the rivers, and to grant American Indians fish and a safe path through them. Nubians also offered the River Nile food and henna.

Nevertheless, during the course of time people became detached from their connection to the rivers and started to manipulate, abuse and interfere with them. They even attempted to control and subjugate them for beneficial purposes. David Groenfeldt in his article "Viewpoint - The Next Nexus? Environmental Ethics, Water Policies, and Climate Change" cites one of the earliest attempts to the "beneficial use" of water; that of the Sri Lankan King Parakramabahu the Great (1153-1186 CE) who famously said: "No drop of water that falls from the sky should be allowed to flow to the sea unused". He implemented his own advice by building reservoirs and canals to command and control the water" (576). It is of great importance to notice that in spite of this use of water for benefit, it did not take place in disregard of the water's 
powers and without taking permission. Groenfeldt declares: "ancient stone sluice gate was constructed in the form of a seven-headed cobra deity. By honouring the water god, the ancient engineers were acknowledging the 'prior appropriation' right of the river spirit, and seeking both permission and protection" (577).

However, this concept of respecting the spirit of the river did not last for long after the scientific revolution which took away the divinity and spirituality out of the rivers and turned them into possessions which do not have "any inherent rights that need to be respected" (Groenfeldt 577). In addition to the industrial revolution which considered that "taming nature was not only a virtue, but a responsibility of those in power" (Groenfeldt 577), Vandana Shiva in her book Staying Alive: Women, Ecology and Survival in India (1988) states: "Industrialism created a limitless appetite for resource exploitation, and modern science provided the ethical and cognitive license to make such exploitation possible, acceptable- and-desirable" (xv).

The worst taming of nature ever has been the building of dams under the pretext of the supposed development. "Dams were built to impound rivers and release the water for power generation, or into canals for irrigation, industry, or urban water supply" (Groenfeldt 576). Shiva comments on this water management and the "destruction (that) is taking place in the name of 'development' and progress," that "there must be something seriously wrong with a concept of progress that threats survival itself" (xiv). That is because ruin often follows the building of dams and the attempts of diverting rivers for purpose of development.

This controversy gives rise to two opposing and rarely tolerant of one another dichotomies; that of valuing the rivers as living gods and that of undermining rivers to resources to be uncheckly exploited and used in the name of development rather than to be let running, "wasted" into the sea. The researcher adopts the notion that development is not an evil or harmful activity in itself, and that the fight must be waged against the environmental and social abuses that are performed in its name. It is our duty to recognize "the existence of alternative social and environmental knowledges that are neither acknowledged nor necessarily understood by development experts in the West" (Huggan and Tiffin 20). This point of view needed to be stressed here for fear of being misunderstood as rejecting all forms of development, what needs to be reconsidered are the forms of development that are of destructive nature that lead to the exploitation of nature, subjugation of women and indigenous cultures and eventually maldevelopment. Before digging deep into the development debate, a historical overview of what inferred the incidents of the novels is of necessity.

The action in the two works of art that are dealt with in this article resulted and are derived from the building of dams; actual dam projects that 
are built on indigenous lands; the "Grand Baleen" dam, based on the building of which is Green Grass, Running Water(1993); (appreviated as GGRW) and the "Aswan High Dam" based on the building of which is Dongola: A Novel of Nubia (trans. 2006). The building of dams affects nature as well as women and indigenous cultures.

\section{The Real Events: A History of Atrocities:}

The events that may be considered as sources of inspiration of the two works of art are real events put into a fictional framework. The main incidents are the building of dams that led to environmental degradation and the forceful dislocation of indigenous people to reservations. The true story behind these fictional works of arts will help us best understand the events and at the same time will help us to realize the trauma that the protagonists experienced and the injustices from which water suffered.

\section{The Grand Baleen Dam:}

James H. Cox in his article ""All This Water Imagery Must Mean Something": Thomas King's Revisions of Narratives of Domination and Conquest in "Green Grass, Running Water" (2000) states that the dam in Green Grass, Running Water is the "'Grand Baleen,"... the name originates with "the Great Whale project in northern Quebec, which was to have been the second phase of the James Bay project" (238).

The official website of The Grand Council of the Crees (GCC) explains their legal struggle against the Great Whale project. The province of Quebec decided in 1986 to build the Great Whale River hydro-electric project to dam and divert almost every major river running into James and Hudson Bays.

According to the GCC website, Hydro-Quebec began the preparation for this project, in which "the Great Whale, the Little Whale, the Coats, and the headwaters of the Nastapoka rivers were to be dammed and diverted to create four reservoirs that would feed three new generating stations, GB 1, 2, and 3, with an installed capacity of 3,060 mw". This diversion resulted in reservoirs of more than three thousand square kilometers in area, and added some 865 square kilometers of flooded land to existing water bodies.

As for the fate of dam in reality, Stratton states: "In 1992, Great Whale suffered a tremendous setback when New York state cancelled its contract to purchase power from Hydro Quebec, the result of a Quebec Cree campaign against further development. In 1994, the project was cancelled altogether" (qtd. in Cox 238).

\section{The Aswan High Dam}


The notion of obstructing water behind a dam in the Aswan region is not a new one as it goes back as far as 1898 (Geiser 188) with the construction of the Aswan Dam, its completion in 1902 and its subsequent heightening in 1912 and again in 1933. However, the Aswan Dam has been an annual way of holding back the water of the Nile in the season of the flood (Ministry of Water Resources and Irrigation website). That is why a permanent way of holding back the water of the Nile is needed in order to grant Egypt "a long-term protection against drought and flood" alike (Abd-El Monsef et al. 1875). Hence, the notion of the construction of the Aswan High Dam is inferred. In 1955 Egypt asked for a loan from the World Bank to build the High Dam. However, according to political issues, Egypt was denied the money. That's why the building of the High Dam became a matter of national challenge. Patrick McCully offers a description of such a situation:

Perhaps more than any other technology, massive dams... symbolize the might of the state that built them, making huge dams a favorite of nation-builders and autocrats. When a dam is given such a powerful symbolic role, its economic and technical rationale and potential negative impacts fade into insignificance in the decision-making process. (1996, 237 qtd. in Huggan and Tiffin 47)

The building of the dam "was given such a powerful symbolic role". It has become the icon of defiance and national pride; national songs have been composed: "We said that we will, and we truly did, build the High Dam".

Nevertheless, the status and rights of the Nubians who have inhabited this region of Egypt for eternity were overlooked and ignored throughout that long course of dam-building history. What happened to the whole community of the Nubians "fade(d) into insignificance in the decision-making process". Nubians have become under-class "victims of ecological disaster" (Huggan and Tiffin 49). Estimates of 50.000 to 70.000 Nubians were resettled in 1964 before the erection of the Aswan High Dam (Jennings 12) with the flooding of 5.000 square miles of their land (White 173). In the name of the "greater common good," Nubians were asked to sacrifice their homes, with the promise of better life conditions. Christine Gilmore states:

resettlement was meant to offer a new beginning. Nasser promised the crowds assembled at Abu Simbel in 1960 that "If the Nubian people are leaving their smaller home of Nubia for the prosperity of the republic ... they will find stability, prosperity and a decent life" in Kom Ombo (Fahim, Egyptian Nubians 36), where they would have access to utilities such as piped water and electricity for the first time as well as better access to health care and education. (Gilmore 55)

The dams in the novels: 


\section{The Grand Baleen Dam in Green Grass, Running Water:}

In King's novel, the officials have waged a psychological war on Eli Stands Alone (one of the protagonists of GGRW) because he lives in his mother's house that "was right in the middle of the proposed spillway for the Grand Baleen Dam" (GGRW 112). They have the habit of opening the gates of the dam "just a little and let the stream come up over the sides of the channel and wash against the logs" (110). Also, in the middle of the night they would turn on the huge search lights of the dam and point it at Eli's house so he could not sleep. Eli describes the dam as "an immense porcelain wall, white and glistening in the late morning light" (110). He says that it "reminds [him] of a toilet" (136).

Clifford Sifton, the designer and builder of the dam in GGRW represents the bureaucratic view of the patriarchal officials. He claims to Eli that "[n]othing personal" (114) and "that's the beauty of dams. They don't have personalities, and they don't have politics. They store water, and they create electricity. That's it" (111). Eli, being well aware of the prejudice of the officials towards American Indians, asks Sifton back: "So how come so many of them are built on Indian land? ... Provincial report recommended three possible sites.... This site wasn't one of them.... None of the recommended sites was on Indian land" (111). Finding no adequate answer to Eli's insightful knowledge, Sifton only denies any responsibility on himself and says: "I just build them, Eli. I just build them" (111). This represents only a small fracture of the injustices that the American Indians have suffered from. Their lands were forcefully and unrightfully depleted in the name of progress even when they are not even recommended for such a development. It is as if the officials know that the Indians are no match for them and that they would take their lands and the Indians would not have a say in it; the worst kind of bias and prejudice ever. Duplessis International Associates, the construction company, has "hired Crosby Johns and Sons Inc., a slick public relations firm in Toronto, to mount a publicity campaign to convince the Indians that the dam was in their best interest" (117), and promised them millions of money, which is a lie. Eli tells Charlie (Eli's nephew, and a Blackfoot lawyer who is hired by Duplessis, just as a front, because "the combination played well in the newspapers" (116)) that "the tribe isn't going to make a cent off that dam. (116) ... the tribe isn't going to make any money off the entire deal" (117). The realities of the injustices that stabbed the American Indians sober cannot be clearer than what King states:

The irony, Charlie mused, was that once Duplessis started construction on the dam, nothing stopped it. Environmental concerns were cast aside. Questions about possible fault lines that 
ran under the dam were dismissed. Native land claims that had been in the courts for over fifty years were shelved.

"Once you start something like this," Duplessis's chief engineer had told an inquiry board, "you can't stop. Too damn dangerous." (118)

The fate of dam differs in the novel than in reality. In King's novel the dam collapses as a result of an earthquake; and the victorious "water rolled on as it had for eternity" (415).

\section{The Aswan High Dam in Dongola:}

None of the promises of better life conditions for Nubians in the resettlement reservation of Kom-Ombo ever come to pass. Nubians were resettled into tin-can of houses, which were made of -as Yahya Mukhtar describes-"stones and cement, with low ceilings, and hot as hell" (qtd. in Gilmore 64). The Nubians felt deceit and agony being banished to Kom-Ombo, paying the dreadful price of the supposed "development" which led to what Rob Nixon terms as the "slow violence" (qtd. in Gilmore 56) of the dam.

In Dongola, the state of anger and despair that resulted from building the High Dam led Awad Shalali, the protagonist, to "bring a lawsuit against the builders of the dam and the reservoir" (31). As lunatic as this idea of bringing a lawsuit against the government seems, Awad eventually left his country and travelled to Europe.

The aggression of the dam was not only against the peoples but also against natural elements. Hesham Abd-El Monsef, Scot E. Smith and Kamal Darwish in their article "Impacts of the Aswan High Dam After 50 Years" hold that since the water is not flushed out annually, the soils are saltier and so less fertile. Also, "coastal erosion is severe in some areas, especially at the Rosetta and Damietta promontories. Efforts to stop the overall coastline retreat have been largely unsuccessful. Other areas of the Egyptian Mediterranean coastline are stable or have accreted" (1873).

This leads us to the notion of development and the feasibility of such development when middling with the course nature intended things to be (including the course of running water).

\section{Development or Mal(e)development:}

From the first beginning of his article "Sacred Rivers, Sacred Dams: Competing Visions of Social Justice and Sustainable Development along the Narmada," William F. Fisher states that whenever there are any interactions among politics, religion, and ecology, "politics usually prevails" (618). In the process of damming rivers, a debate rises whether rivers are to be treated as gods or as development resources which leads to the conflicting issue between social justice and sustainable development. The former's point of view, Fisher 
explains, is that rivers are sacred, and that they form "a timeless environment" that the indigenous cultures treat with respect and honor and they represent an integral part of these rivers. To contrast this view of the timeless sacredness of rivers is the latter's view of a river as "a resource", supporting the

modernist convictions that one can obtain mastery over nature, and that the failure to do so will mean ruin. It derives from the conviction that as humans we can and must make our own destiny, that human history has been a history of progress, and that we can find technological solutions to all the problems we encounter. (Fisher 624)

This notion of development represents the perspective that Ecofeminism always fights against; that of viewing nature as both threatening and dangerous and needs to be subdued and at the same time represents the only place where their much-needed resources lie.

That is why these so-called developers always resorted to a strategy that never failed them; that of expropriation. Western invaders have taken advantage of the American Indian notion of nature as a shared property of all beings, that no property rights can be claimed when life-supporting organisms as rivers are the matter of debate. However, in the view point of Westerners, Longo and Miewald argue, "Indians appeared to squander the resources that were available to them. Indian poverty (the Westerners' notion of poverty, of course) was the result of Indian waste: underused land, underused natural abundance, underused human labor" (56). And that is why, in the view of Westerners, these "savage" and underdeveloped peoples cannot have "legal status and rights" similar to those of the "civilized" peoples. That is why "land could justifiably be appropriated... it was unthinkable that regressive attitudes, even in the name of religion, should stand in the way of greater good" (56-57, my emphasis). These notions of possession and use-value under the guise of "development, progress and prosperity" signal the destruction of water supply, land and the animals living upon it, as well as the native American Indian ways. The Western consideration of American Indian land as unused and "empty land", as what Cheryl Lousley terms it, "not only refers to a racist erasure of indigenous cultures and political communities, but also represents a particular configuring of nature in the service of national development" (qtd. in Huggan and Tiffin 166-167).

Huggan and Tiffin also argue that the settlers, who rarely respected the cultures and philosophies of indigenous cultures, have "tended to conceive of themselves as conferring (or imposing) the gifts of civilisation upon the benighted heathen with little or no interest in receiving his or her philosophical gifts in return" (7).

Fisher states that there are "three practical consequences that emerge from the attempt to conquer nature." First, the "redistribution" of the resources 
is done without the consent of the indigenous people. "Second, this diversion of natural resources is done in such a way that it entails further alteration and domination of nature. Third, the process allows and even requires that governments consolidate their control over both resources and people" (625). This unjust takeover and exploitation of indigenous lands is opposed to the "ecofeminist culture and ethic, (where) mutual interdependency replaces the hierarchies of domination as the model of relationship between men and women, between human groups and between humans and other beings" (Ruether 354).

Despite all of the atrocities that the indigenous cultures endured in the name of development, and as a result of interfering with and changing the course of nature, (especially water, through the building of dams) any progress that has been hoped for eventually turns out to be destruction. This destruction takes place as a result of those in power applying understudied Western patriarchal methods and technological means that do not fit in their domestic ecological systems. These Western technological means are used to dominate and control nature, which have led to what Shiva calls "systematic underdevelopment" or "maldevelopment". "This destroying (of) subsistence economies and maldevelopment projects" Warren explains, "created material poverty where, before, there had been none" (Warren 2015). The worst sufferers of this poverty are women. "Feminization of poverty", subordination of women, and degradation of nature are of the consequences of such interference with the natural course of rivers through the building of dams (Warren 2015).

Catriona Sandilands in her book The Good-Natured Feminist: Ecofeminism and the Quest for Democracy (1999) coins the term "mal(e)development" referring to the maldevelopment that is done by males. Shiva indicates that according to Evelyn F. Keller "science has been produced by a patriarchal sub-set of the human race, that is, almost entirely by white, middle class males.... [T] hey sought a philosophy that deserved to be called 'masculine', that could be distinguished... (by) its capacity to bind Nature to man's service and make her his slave" (qtd. in Shiva 15). It must be noted that it is not a matter of male-female controversy, but rather the notion of Patriarchy versus the feminine principle of handling matters of oppressive dualisms and patriarchal destruction of earth in most development projects. Males who have put themselves in a higher status than both women and nature and inferred hierarchal positions that only lead to patriarchy and its subsequent notion of othering, whether this other is nature, woman, or indigenous people.

Of benefit to analyzing this notion of othering is Ecofeminism's reflection on how the dependence on culture and technology that dominate and control nature only lead to further alienation of humans (especially white 
males) from nature, which by its turn lead to the ignorance of how deep dependent humans are on the very nature they are destroying.

That is why Shiva suggests that "development was thus reduced to a continuation of the process of colonization" (1). Colonization this time does not occur by means of soldiers and fighters, but by means of culture, technology and "modern western patriarchy's economic vision" (1). This postcolonial notion of "development" is only a continuum of the previous colonization process. This economic vision is based on the triple exploitation of women, nature, and other cultures. That is why "women, peasants and tribals are struggling for liberation from 'development' just as they earlier struggled for liberation from colonialism" (2). Shiva stresses the idea "economic growth was a new colonialism, draining resources away from those who needed them most" (2). It is now "new national elites, not colonial powers" that exploit nature and expropriate indigenous cultures who are deeply attached to it, and this injustice is performed on the grounds of "national interest."

The importance of the application of the feminine principle -with its notion of holism and respect of the characteristics of nurturing and compassion- is underscored throughout the article. Nevertheless, Rajni Kothari (1988), founder of "Centre for the Study of Developing Societies" in Delhi, in his Foreword to Shiva's Staying Alive, warns us from the misconception between "the holism implied in the feminine principle" and "the universalism of the modern scientific era" (viii). According to him, the former respects diversity and appreciates "the whole issue of ethnicity, of the struggles of minorities and marginalised communities," while the latter "undermines (diversity) under its homogenising and centralising thrust and, in the end, destroys diversity" (viii). Huggan and Tiffin also support this notion of destructive universalism "that disguises specific race, class, gender and, for that matter, species interests" (206). Universalism is also attacked for "providing an intellectual rationale for the imperial civilising mission and other authoritarian regimes and systems which, consciously or unconsciously, have abused humanity in humanity's name" (206; my emphasis).

\section{Maldevelopment in Green Grass, Running Water:}

Thomas King in Green Grass, Running Water asserts the notion of injustice when Coyote asks for a turn to tell the story. "'In a democracy, everyone gets a turn," says Coyote. "Nonsense," I says. "In a democracy, only people who can afford it get a turn"" (327). King also asserts that Westerners would pay any regard to whatever or whoever is in their way towards profit. King describes their disregard of what may befall the house of Eli's mother, whether "it was flooded or torn down or whatever they did to things like that that were in the way of progress" (113). 
In GGRW, the concept of "civilizing" the American Indians is presented through the character of "Robinson Crusoe" who thinks of himself as a guardian or custodian of the people of color, only because he is 'white'. He addresses "Thought Woman" -that mighty woman who, according to the American Indian belief, is capable of creating anything just by the mere thinking of $i^{1}{ }^{1}$ - without him paying the slightest attempt to try to know her own powers and knowledges that may exceed that of his own, and says:

Under the bad points, says Robinson Crusoe, as a civilized white man, it has been difficult not having someone of color around whom I could educate and protect.

What's the good point? says Thought Woman.

Now, you're here, says Robinson Crusoe. (294)

\section{Maldevelopment in Dongola:}

The mal(e)development that the Nubians endured during the building of successive dams during the $20^{\text {th }}$ century is best represented by Huggan and Tiffin's expression of the side effect of universalism's: "(to) abuse humanity in humanity's name" (206). For the best interest of north Egypt, they had to be uprooted and resettled in the name of development that will result from the building of dams. Their homeland became the "reservoir" of the north (Dongola 24). In addition, Christine Gilmore in her analysis of Nubian works of art handles the motif of modern universalism and its deliberate ignorance and erosion of the uniqueness of minor cultures as well as these minorities' needs on the pretext of national unity. She argues that Nubian literatures "articulate a distinctively Nubian identity, in the face of the twin threats of Arabization and assimilation, reclaiming Egypt's marginalized African heritage as an integral part of what it means to be Egyptian" (53). Dongola is to be seen as what Gilmore terms "minor literature" that lies within a "major voice". Though it is written in Arabic, Ali incorporates in them some Nubian words and terms -i.e. hamboul, gorbati, adamir, amon dugur and amon nutto, adila...etc.- and Nubian exclamations -i.e. ibibibib, ibiyuuu ibiyu, and wonor; "promoting a broader conception of Egyptian identity that celebrates, rather than silences, Egypt's inherent ethnic and religious pluralism" (Gilmore 61$62)$.

The next section handles the injustices that have resulted from modern mal(e)development and the building of dams that are suffered by the American Indians and Nubians in general and women in particular, as well as the

\footnotetext{
${ }^{1}$ Leslie Marmon Silko in her essay "Landscape, History, and the Pueblo Imagination" indicates that Thought Woman, the Spider, thought about creation, and everything she thought came into being.
} 
injustices against natural elements in general and water in particular, and how all these kinds of injustices correlate and correspond to each other.

\section{The building of dams as an aggression towards indigenous cultures:}

American Indians have inhabited the continent now known as America for thousands of years before the arrival of Columbus to it. And since that discovery, American Indians suffered the worst of injustices: subjugation, expropriation, forced migration, prison, and even mass murders. Entire tribes had been whipped out and people had been put in prison for no crime committed other that being an Indian. Thomas king asserts this truth more than one time in his novel Green Grass, Running Water. When First Woman is taken to jail in Fort Marion and she asks about her charge, she is answered: "Being Indian" (GGRW 72). And to contrast the truth, American Indians were stereotyped as savages who would kill "a beautiful blond woman, her hands raised in surrender, watching horrified as a fearsome Indian with a lance rode her down" (160).

The title of Green Grass, Running Water itself is a memoir of the injustices done to American Indians. It is an allegory of "As long as the grass is green and the waters run," a statement always written in treaties with American Indians to indicate the eternity of the treaty, which is, and always had been, a lie. King explains this view: "As long as the grass is green and the waters run. It was a nice phrase, all right. But it didn't mean anything. It was a metaphor. Eli knew that. Every Indian on the reserve knew that. Treaties were hardly sacred documents. They were contracts, and no one signed a contract for eternity. No one" (267). Water is no longer running. It is held back and dammed to death. The grass is no longer green, for it has died out of thirst. Governments "felt generous back in the last ice age, and made promises it never intended to keep" (138). Longo and Miewald quote what Wilkinson (1987) has contended in a courtroom that "the judges cannot shake their commitment to old contracts and treaties, "typically conducted in but a few days on hot, dry plains between midlevel federal bureaucrats and seemingly rag tag Indian leaders"" (61).

Sifton, the closest thing to the antagonist of the novel, tells Eli that "those treaties aren't worth a damn. Government only made them for convenience. Who'd of guessed that there would still be Indians kicking around in the twentieth century" (141). Westerners do not deal with American Indians as a present, but rather as what Andy Smith describes as "'early" people and not contemporary people who face contemporary problems.... [M] [Minstream society portrays Indians as people who had a romantic past, but people who have no place in modern society" (30-31). King in GGRW expresses this notion of treating American Indians as a history not as a real fact that is still surviving 
in the present when a tourist named Archie says: "What we really want to see ... are the Indians" (158), as if Indians were preserved antiquities, animals in a zoo or freaks in a show.

This same notion, Gilmore argues, is also applicable to Nubians. She argues that:

the loss of "home-ground" or "Nile World" that provided the "ontological grounding of their culture"... leads the villagers to reflect on the existing threat posed by resettlement to the continued viability of Nubian culture as a living tradition as opposed to a historical artifact to be "mummified" by ethnologists and put in a museum. (64-65)

Haggag Oddoul in his critical book $O^{\prime} d a b a^{\prime}$ Nubeiun wa Nuqqad Onsureiun (2006) (Nubian Writers and Racial Critics) traces the notion that that Nubia is a museum and a folklore, and that Nubians are those dark and kind people who work as doormen, waiters and cooks. Oddoul argues that Nubians are accepted only within this stereotype. However, at the slightest attempt to resist this stereotype and be successful people who present their life pains and their hopes, to have a genuine desire to live their "Nubianness" and be obliged to their duties as well as enjoying their rights; they are totally rejected, especially by the racial sector of common people and the semi-cultured alike, who need to practice their prejudice upon peoples who they tend to treat as "others" (59).

Now the study handles the history of Nubians as well as some of the atrocities from which they suffered. Nubians are an ethnic group that has inhabited the region that extends from the First Cataract near Aswan and up to the Fourth Cataract in the Republic of North Sudan. In ancient times, the Nubian homeland had extended to the Six Cataract near the ancient Meroë, near modern Khartoum (Jennings 19). There had been times when Nubians had formed strong kingdoms such as Kush or Nabata (Gilmore 53) that had entwined relationships with ancient Egypt for centuries (Jennings 19). It had been named "the gateway to Africa" (Gilmore 53), and the "Land of Gold". Idris Ali states that the Nubians had been called by Arabs as "the bowmen of the glance" because they aimed only with their eyes when they shot their arrows, never missing (Dongola 1). Nevertheless, ever since early times, Nubians suffered from aggression against them, and from raids of invaders who "headed south in search of ostrich feathers, musk, crocodile skins, livestock, and the gold they snatched from the arms and necks of women" (Dongola 26). They had targeted their gold and even Nubian men had been captured as slaves.

The northerners, instead of feeling gratitude to the Nubians, further scorned the Nubians who knew nothing but farming and who had nothing left 
but to work in underestimated jobs. The Nubians were expelled from their land which is now submerged under the Nile, forming "the reservoir of the north" which granted the northerners sustainable water log that enables "an over-year water supply capacity and so provides year-round irrigation water. This capacity has, effectively, transformed the entire irrigation system to a perennial one. Three crop seasons are used and Egypt's total food production has increased as a result" (Abd-El Monsef et al. 1877). Those who benefited from this food production are the people of the north, not the Nubians who still live in harsh social and economic conditions, and yet Nubians are the ones who had paid, and still, the harsh price. "Ever since losing their land," Ali describes, they suffered "[d]rought and famine." Awad remembers his "miserable childhood" when "he ate rotten pickled fish called tarkeen, left uneaten even by the dogs" (23).

Ali describes how their status as doormen and waiters, a status that Nubians never choose but had been forced to accept, has been used as a way to further subjugate them; along with their color of complexion. He states a conversation between Awad and a police officer who has been interrogating him before sending him to a ten-year-prison sentence:

"Sign here."

"I insist on reading the transcript of the interrogation. I'm not illiterate."

"We're the ones who taught you how to read, you son of a slave." "I object. My mother is a free Nubian lady."

... "The government was wrong to give you people schools. If we had left you savages, you'd still be our waiters and doormen. Take this man away and teach him some manners." (16)

Epidemic and endemic diseases have spread among Nubians, taking the lives of children and elders alike. "[E]pidemics killed many of (Awad's) friends: malaria, cholera, yellow fever, and tuberculosis, to say nothing of scorpion stings and snake bites. It was a forgotten land, which the world had erased from its map, to serve as a reservoir for its water" (24). They had no clinics and no doctors, "the village's resident doctor was an ignorant barber" (23). That is why "the road to the cemetery was often visited" (23).

This case of diseases that spread among the indigenous Nubians; as well as the spread of alcoholism is also true for American Indians. Shiva in her book Staying Alive states that this notion of alcoholism as a form of "lifedestroying activities" that are practiced by "societies (that) have been colonised and broken up," is due to the status of "all ecological societies of forestdwellers and peasants, whose life is organised on the principle of sustainability and the reproduction of life in all its richness, (which) embody the feminine principle" (41). When forced to migrate and relocate, and their old way of life is devastated, they have suffered a severe social, psychological and even 
physical illnesses that could only be cured through forgetfulness, which they could achieve through drinking "arak" or "aragi" -an alcoholic drink made from dates- as in the Nubian case, and alcohol and drugs as in the American Indian one.

Idris Ali in Dongola presents the characters of Awad Shalali and Abdu Shindi. They both drink alcohol or the domestic "arak" heavily in order to forget their loss; their lost land. It is the worst of traumas as Nubians had no chance or hope of getting back what they had forever lost. Ali narrates that Awad "bought a bottle of arak... and drank and drank until nothing was left. He dropped off the train reeling and singing My land. He found Shindi, who was also getting drunk alone under a slender palm tree; ... he (Awad) sat down and wept from the pain of drunkenness and injustice" (38-39).

Walter Muma describes such a status of American Indians after the building of the Quebec project at James Bay as:

Alcoholism and all of the other related problems descended on them and tore apart their established way of life that was thousands of years old. They experienced staggering social problems brought on by the huge influx of outsiders, such as alcohol and drug abuse, prostitution, family violence, etc, problems which continue today.

Drunkenness has also been the only cure left for their bodies as well as their souls. Even the healing plants, as a result of the building of the dam, have been destroyed.

\section{Conclusion}

Depending on this view of American Indian and Nubian literatures, it can be inferred that both cultures endured severe physical as well as psychological injustices as a result of building dams. They suffered from displacement, alienation, and exile, as well as unemployment and alcoholism. In addition to them, the dammed rivers experienced ecological aggression that resulted from applying underdeveloped, ready-made, Western schemes that were applied without being adjusted to the environments that they were applied to. The building of these dams caused American Indians and Nubians to be deterritorialized from their homelands that they could nurture, and be reterritorialized into reservations that did not provide them their basic needs, and also denied them their sense of self which is deeply related to their sense of place.

\section{Works cited}


Abd-El Monsef, Hesham, Scot E. Smith and Kamal Darwish. " Impacts of the Aswan High Dam After 50 Years." Water Resour Manage, 29 (2015): 1873-1885. Print.

Allen, Paula Gunn. "The Sacred Hoop: A Contemporary Perspective." The Ecocriticism Reader: Landmarks in Literary Ecology. Ed. Cheryll Glotfelty and Harold Fromm. Athens, Georgia: the University of Georgia Press. 1996.

Cox, James H. ""All This Water Imagery Must Mean Something": Thomas King's Revisions of Narratives of Domination and Conquest in "Green Grass, Running Water"." American Indian Quarterly, 24.2 (2000): 219-246. Print.

Donaldson, John K. "As Long as the Waters Shall Run: The "Obstructed Water" Metaphor in American Indian Fiction." American Studies International 40.2 (2002): 73-94. Print.

Dreese, Donelle N. "Ecocriticism: Creating Self and Place in Environmental and American Indian Literatures". New York: Peter Lang Publishing, Inc. 2002.

Evernden, Neil. "Beyond Ecology: Self, Place, and the Pathetic Fallacy." The Ecocriticism Reader: Landmarks in Literary Ecology. Ed. Cheryll Glotfelty and Harold Fromm. Athens, Georgia: the University of Georgia Press. 1996. Print.

Fisher, William F. "Sacred Rivers, Sacred Dams: Competing Visions of Social Justice and Sustainable Development along the Narmada." in Gottlieb, (ed.) This Sacred Earth: Religion, Nature, Environment. New York and London: Routledge, 2nd Edition. 2003.

Geiser, Peter. "The Myth of the Dam." American Anthropologist, New Series 75.1 (1973): 184-194. Print.

Gilmore, Christine. ""A Minor Literature in a Major Voice": Narrating Nubian Identity in contemporary Egypt. Alif 35 (2015): 52-74.

Groenfeldt, David. "Viewpoint - The Next Nexus? Environmental Ethics, Water Policies, and Climate Change." Water Alternatives 3.3 (2010): 575-586. Print.

Huggan, Graham and Helen Tiffin. "Postcolonial Ecocriticism". Routledge, 2010.

Jennings, Anne M. "The Nubians of West Aswan: Village Women in the Midst of Change." USA: Lynne Reinner Publishers. 1995. 
Lavally, Giselle Rene. "'One Tricky Coyote": The fiction of Thomas King." Thesis and Dissertations (Comprehensive). Paper 2. Wilfrid Laurier University. 1996. Web. URL: http://scholars.wlu.ca/etd/2.

Longo, Peter J. and Christiana E. Miewald. "Native Americans, The Courts and Water Policy: Is Nothing Sacred?" Great Plains Research 2.1 (1992): 51-66. Web. URL: http://www.jstor.org/stable/23775751. Accessed: 23-5-2016 at 10:19 UTC.

Muma, Walter. "Hydro-Quebec Project." James Bay Road Website. Accessed: 23-8-2016 at 13:32 UTC. Used with permission. URL: http://www.jamesbayroad.com/hydro/index.html

Ruether, Rosemary R. "Ecofeminism: Symbolic and Social Connections of the Oppression of Women and the Domination of Nature" in Gottlieb, (ed.) This Sacred Earth: Religion, Nature, Environment. New York and London: Routledge, 2nd Edition. 2003.

Said, Edward W. "Reflections on Exile." Reflections on Exile and Other Essays. Cambridge, Mass.: Harvard University Press. 2000. Print.

Sandilands, Catriona. "The Good-Natured Feminist: Ecofeminism and the Quest for Democracy." Minneapolis, London: University of Minnesota Press. 1999.

Shiva, Vandana."Staying Alive: Women, Ecology and Survival in India." London: Zed Books Ltd., 1988.

Silko, Leslie Marmon. "Landscape, History, and the Pueblo Imagination." The Ecocriticism Reader: Landmarks in Literary Ecology. Ed. Cheryll Glotfelty and Harold Fromm. Athens, Georgia: the University of Georgia Press. 1996.

Tillman, Benjamin. "The White Man's Burden and the Philippines."

Congressional Record (February 7, 1899): 1529-1533. Web. URL: https://en.wikisource.org/wiki/Benjamin_Tillman_7_February_1899. Accessed: Sep 6, 2016 at 16:30 UTC.

Warren, Karen J. "Feminist Environmental Philosophy". The Stanford Encyclopedia of Philosophy, Edward N. Zalta (ed.) Summer 2015 edition. Web. URL: http://plato.stanford.edu/entries/feminismenvironmental/

White, Lynn. "The Historical Roots of our Ecological Crisis." This Sacred Earth: Religion, Nature, Environment. Ed. Roger Gottlieb. New York and London: Routledge, 2nd Edition. 2003. 
أدّول, حجاج حسن. "أدباء نوبيون ونقاد عنصريون." القاهرة: مركز القاهرة لدراسات حقوق الانسان. .2006 فهمي, ابر اهيم. "النوبة أرض العطر والذهب: رؤية من الداخل." بافا للار اسات و النشر. 1990.

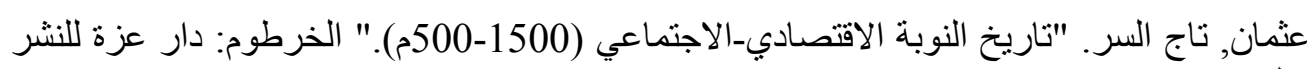
و التوزيع. 2003. 